\title{
TINGKAT PENGETAHUAN PETERNAK TERHADAP BERAT BADAN BROILER DENGAN VARIASI SUHU PADA SISTEM PEMELIHARAAN KANDANG CLOSED HOUSE
}

\section{Farmer Knowledge Level of Broiler Body Weight With Temperature Variations In Closed House Cage Maintenance System}

\author{
Bainati Nurjannah*, Mufidah Muis, Arief Sirajuddin S, dan Hartina Beddu \\ Politeknik Pembangunan Pertanian Gowa \\ Jl Malino km 7. Romanglompoa, Kecamatan Bontomarannu, Kabupatan Gowa Provinsi Sulawesi Selatan \\ *e-mail: bainatinurjannah@gmail.com
}

Received: 24 September 2021; Accepted: 25 November 2021; Published: 25 Desember 2021

\begin{abstract}
ABSTRAK
Kajian ini bertujuan untuk mengetahui perbedaan berat badan ayam broiler dengan variasi suhu yang berbeda pada sistem pemeliharaan kandang closed house.Pengumpulan data kajian dilakukan dengan tabulasi data hasil pencatatan suhu dan penimbangan berat badan ayam, sedangkan data penyuluhan diperoleh dari pengumpulan data primer dilakukan dengan cara wawancara dengan peternak secara langsung dengan menggunakan kuesioner. Parameter yang diamati meliputi suhu kandang closed house (X) dan berat badan ayam (Y). Kajian ini diteliti mulai umur 12 hari sampai 21 hari dengan menggunkan 3 sekatan dan setiap sekatan berisi 5.000 ekor. Kajian ini dilakukan pengambilan data 3 kali sehari dengan dengan 10 sampel ayam per sekatan. Penelitian ini mencatat suhu setiap kandang dan menimbang berat badan ayam yang ada pada sekatan hingga mendapatkan 81 data. Data dianalisis menggunakan korelasi product moment pearson $(\mathrm{X}=\mathrm{Y})$. Hasil yang didapatkan bahwa sekatan 1 yang paling bagus pertumbuhan berat badan akhir (umur 21 hari) adalah 1,03 $\mathrm{Kg}$ /ekor ayam dengan suhu berkisar $25-29^{\circ} \mathrm{C}$. Hasil kajian menggunakan analisis korelasi product moment pearson antara suhu dengan berat badan ayam (Kg/Ekor) (r) adalah $-0,594$ ini menunjukkan bahwa terjadi hubungan yang tinggi antara suhu dengan berat badan ayam (Kg/Ekor) karena nilai $\mathrm{r}$ negatif berarti semakin tinggi suhu maka semakin menurunkan berat badan ayam (Kg/Ekor). Pelaksanaan penyuluhan mendapatkan hasil perubahan pengetahuan responden $32,1 \%$ dan efektivitas penyuluhan mencapai $64,3 \%$ dengan demikian penyuluhan yang dilaksanakan cukup efektif.
\end{abstract}

Kata kunci: Tingkat pengetahuan, variasi suhu, sistem pemeliharaan, kandang closed house

\section{ABSTRACT}

This research aims to observe the difference in broiler chicken with variations of room temperature in a closed house coop. Data collection was retrieved from the tabulation of regular checking on broiler chicken, temperature, and weight. The primary data was collected from a questionnaire filled by farmers. Parameters observed in this study are closed house $(X)$, temperature $(Y)$. Research subjects are 12-21 days old chicken put in a chicken coop with around 5000 chicken in each partition. Samples are taken every three days for ten chicken in every observation. The total observation data are 81 and were run using product moment Pearson $(X=Y)$. Our findings confirmed that partition number one has the best result with average weight $1,03 \mathrm{~kg} /$ chicken (21 days old), with temperature $25-29^{\circ} \mathrm{C}$. Analysis using product moment Pearson showed a negative correlation as -0,594 (high r-value), which means temperature and weight have a different

Diterbitkan Oleh, 
association. The higher the temperature, the lighter the weight of chickens are. The improvement of respondents on knowledge is $32,1 \%$, and counseling effectivity is $64,3 \%$, displaying effective counseling.

\section{Keywords : Knowledge level, weight, broiler chicken, temperature, closed house coop}

\section{PENDAHULUAN}

Peternakan merupakan salah satu sub sektor pertanian yang memegang peranan penting dalam penumbuhan kebutuhan protein hewani di masyarakat. Meingkatkanya jumlah penduduk dan tingkat pendapatan masyarakat akan menyebabkan meningkatnya permintaan akan pangan asal hewani. Talib dkk. (2007) menyatakan bahwa dalam hal pemenuhan kebutuhan daging unggas Indonesia telah mencapai swasembada sejak tahun 1995. Salah satu usaha untuk memenuhi ketersediaan akan pangan asal hewani adalah usaha peternakan ayam ras pedaging atau biasa disebut dengan ayam broiler.

Ayam broiler adalah ayam yang dipelihara relative singkat, sehingga pada umur 5-6 minggu sudah bisa di panen, dan memiliki konversi pakan yang rendah (Prihatman, 2002). Berdasarkan potensi peternakan Desa Bunga Ejaya yang ada di Kantor Desa Bunga Ejaya, Kecamatan Pallangga, Kabupaten Gowa (2020), diketahui bahwa ayam merupakan populasi ternak tertinggi dan jumlah populasi ayam broiler sebanyak 30.000 ekor. Mengingat besarnya kerugian yang didapatkan oleh peternak apabila terjadi perbedaan berat badan ayam broiler disebabkan oleh suhu kandang yang tidak tepat sehingga menyebabkan berbedaan harga penjualan pada ayam broiler dikarenakan kurangnya pengetahuan peternak terhadap pemeliharaan ayam broiler, maka perlu dianalisis penyebab dan solusi masalah tersebut.

Suhu merupakan salah satu faktor lingkungan yang dapat mempengaruhi performa ayam broiler. Indonesia sebagai negara tropis, memiliki suhu lingkungan yang lebih tinggi atau berada di atas zona nyaman bagi pertumbuhan ayam ras pedaging atau ayam broiler. Pertumbuhan optimal ayam broiler tercapai apabila berada pada suhu lingkungan yang nyaman, yaitu $18-23^{\circ} \mathrm{C}$ (Bell dan Weaver, 2002) dan dilanjutkan penelitian Anas (2016) mengatakan bahwa ayam broiler dapat tumbuh dengan optimal pada temperature suhu 19$21^{\circ} \mathrm{C}$, sedangkan suhu di Indonesia dapat mencapai $33-35^{\circ} \mathrm{C}$ pada musim kemarau. Sehingga perlu adanya kandang yang dapat mengatasinya. Suhu lingkungan penelitian yang lebih tinggi dari suhu nyaman ayam broiler dapat mempengaruhi performa ayam untuk tumbuh maksimum.

\section{METODE PELAKSANAAN}

\section{Tempat dan Waktu}

Kegiatan penelitian ini dilaksanakan di Kampus II Politeknik Pembangunan Pertanian Gowa, sedangkan kegiatan Tugas Akhir dilaksanakan pada bulan Maret sampai dengan bulan April 2020 dan pelaksanaan penyuluhan dilaksanakan bulan Mei 2020 di Desa Bunga Ejaya, Kecamatan Pallangga, Kabupaten Gowa, Provinsi Sulawesi Selatan.

\section{Alat dan Bahan}

Adapun alat yang digunakan dalam kajian yaitu tempat pakan, tempat air minum, thermometer, karung, timbangan, kamera, alat tulis menulis (pulpen, buku, spidol). Sedangkan alat yang digunakan dalam kegiatan penyuluhan yaitu: kuesiner, lembar persiapan penyuluhan (LPM), Labtop dan kertas kuarto. Sedangkan kegiatan Tugas Akhir menggunakan bahan yang didalam kajian yang diperlukan yaitu: tali raffia, air mineral, desinfektan, pakan komersial, ayam broiler berumur 12 hari. Sedangkan bahan yang digunakan dalam kegiatan penyuluhan yang digunakan adalah folder/leaflet.

\section{Metode Pelaksanaan}

Metode yang digunakan dalam kajian ini yaitu menggunakan analisis korelasi. Parameter pengamatan adalah suhu dalam kandang closed house (X) dan berat badan ayam broiler (Y). Proses penyimpanan thermometer diletakkan pada setiap sekatan kandang. Kandang ayam broiler terdiri dari 4 sekatan tetapi, hanya 3 sekatan yang digunakan dalam penelitian ini dan setiap sekatan berjumlah 5.000 ekor. Jumlah ayam broiler didalam kandang closed house terdiri dari 20.000 ekor. Penelitian dilakukan 3 kali sehari dengan mencatat suhu setiap 
kandang dan menimbang berat badan ayam yang ada pada sekatan hingga mendapatkan 81 data. Pencatatan suhu dan berat badan ayam dilakukan secara acak dengan menggunakan 10 sampel ayam per sekatan setiap penimbangan dan pencatatan suhu setiap sekatan kandang sesuai jumlah unit percobaan. Ukuran kandang yang digunakan adalah $12 \times 30 \mathrm{~cm}$ persekatan

\section{Teknik Pengumpulan Data}

Teknik pengumpulan data dengan cara wawancara dengan petani/peternak secara langsung dan mengamati langsung objek yang diteliti. Untuk memperoleh data sekunder, dilakukan dengan mengunjungi kantor Desa untuk mencari data penunjang dalam pelaksanaan kajian.

\section{Analisis Data}

Metode analisis data yang digunakan dalam kajian ini yaitu data yang diperoleh diolah dengan sidik ragam sesuai dengan metode korelasional. Metode korelasi digunakan untuk menentukan besarnya koefisiensi korelasi jika data yang digunakan berskala interval atau rasio. Variabel dalam penelitian ini meliputi satu variabel bebas yaitu suhu dalam kandang closed house (X), serta satu variabel terkait yaitu berat badan ayam broiler (Y). Berikut ini adalah skema hubungan variabel $\mathrm{x}$ dengan variabel $\mathrm{y}$.

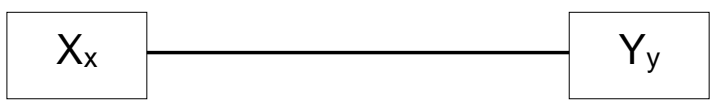

Gambar 1. Skema hubungan variabel $\mathrm{x}$ dengan variabel y

Rumus yang digunakan yaitu korelasi product moment dari Karl Pearson. Rumus korelasi product moment menurut Suharsimi Arikunto (2002)

Perhitungan tersebut diperoleh melalui bantuan program SPSS 16. Kekuatan hubungan antara dua variabel ditentukan berdasarkan kriteria Sarwono (2006).

\section{Analisis Penyuluhan}

Untuk menganalisis penyuluhan dilakukan dengan cara mengevaluasi kegiatan penyuluhan yaitu dengan mengukur tingkat pengetahuan petani/peternak dengan pembagian kuesioner dengan jumlah 10 pertanyaan, jawaban skor tertinggi nilainya 4 dan jawaban skor terendah nilainya 1.

\section{Rancangan Penyuluhan}

Penyusunan rancangan penyuluhan dilakukan melalui tahapan berikut:

\section{Penetapan Materi}

Penetapan materi penyuluhan dilaksanakan dengan mempertimbangkan aspek teknis, sosial dan ekonomi, apabila dapat menguntungkan dan secara sosial dapat diterima oleh sasaran. Oleh karena itu materi rancangan penyuluhan harus disesuaikan dengan karakteristik peternak, kebijakan daerah dan potensi wilayah.

\section{Metode Penyuluhan}

Metode dalam proses penyuluhan yaitu metode pendekatan individu dan kelompok. Pendekatan individu (perorangan) adalah proses penyampaian materi penyuluhan dengan wawancara langsung terkait materi yang akan disampaikan, sedangkan pendekatan kelompok adalah penyampaian materi penyuluhan secara langsung dan berdiskusi dengan beberapa anggota kelompok tani.

\section{Teknik Penyuluhan}

Teknik penyuluhan yang dilakukan yaitu wawancara, ceramah, dan diskusi. Dalam metode pendekatan individu digunakan teknik wawancara terkait dengan materi yang akan disampaikan. Metode pendekatan kelompok dilakukan dengan ceramah dan berdiskusi dengan peternak. Kegiatan diskusi dilakukan agar peternak dapat lebih bebas bertanya dengan begini peternak dan mahasiswa saling bertukar informasi dan peternak lebih cepat paham dengan materi yang disampaikan.

\section{Media Penyuluhan}

Kegiatan penyuluhan dilengkapi juga dengan folder. Hal ini dilakukan sebagai upaya untuk lebih mempermudah dalam penyampaian materi dan meyakinkan peternak tentang suhu yang baik/ideal bagi pertumbuhan berat badan ayam ras pedaging/broiler, agar peternak mau mengadopsi teknologi informasi yang disampaikan dengan cara mengaplikasikan pada kandang ternaknya. 


\section{Evaluasi Desain Penyuluhan}

\section{Menetapkan Tujuan Evaluasi}

Evaluasi terdiri dari evaluasi awal dan evaluasi akhir. Metode yang digunakan untuk menganalisis tingkat respon petani/peternak terhadap materi penyuluhan adalah menggunakan skala likert kemudian ditabulasi dalam bentuk garis continuum (Padmowihardo, 2012). Untuk mengetahui tingkat pengetahuan petani/peternak digunakan kuesioner yaitu menggambarkan pengetahuan petani/peternak menggunakan data skala original (skala likert) sedangkan alat ukur tingkat pengetahuan menggunakan skala Rating scale. Adapun skornya yang digunakan adalah skor 4 sangat mengetahui (SM), skor 3 mengetahui (M), skor 2 kurang mengetahui (KS), skor 1 tidak mengetahui (TM).

\section{Memilih Metode Evaluasi}

\section{Wawancara}

Wawancara merupakan metode yang paling banyak digunakan untuk evaluasi program, termasuk evaluasi penyuluhan. Wawancara dilakukan dengan menggunakan kusioner dengan tujuan untuk menggali masalah secara mendalam.

\section{Observasi}

Pengamatan bisa orang luar atau orangorang yang terlibat dalam kegiatan penyuluhan. Pengamatan biasanya diberi daftar pendek item yang mungkin termasuk tingkat prestasi dan interaksi pribadi, indikator nonverbal kepentingan atau perhatian, peran kepemimpinan, tingkat kinerja dan indikator konflik.

\section{Instrument Evaluasi Penyuluhan}

Mempersiapkan instrument penyuluhan bertujuan untuk mengetahui tingkat pengetahuan petani/peternak digunakan kuesioner yaitu menggambarkan sikap peternak dengan menggunakan data skala original (skala likert) sedangkan alat ukur tingkat pengetahuan menggunakan Rating scale. Adapun skornya yang digunakan adalah skor 4 sangat mengetahui (SM), skor 3 mengetahui (M), skor 2 kurang mengetahui (KM), skor 1 tidak mengetahui (TM).

\section{Populasi dan Sampel}

Sampel yang digunakan diambil dengan menggunakan sampling jenuh. Sugiyoni (2010) sampling jenuh adalah teknik penetuan sampel bila semua anggota populasi digunakan sebagai sampel. Dalam kajian ini digunakan seluruh anggota kelompok tani (25 orang) dijadikan sebagai sampel.

\section{Evaluasi Hasil Penyuluhan}

Metode evaluasi kegiatan penyuluhan yang akan digunakan yaitu dengan menggunakan skala likert untuk mengetahui tingkat pengetahuan berdasarkan hasil jawaban petani/peternak pada kusioner awal dan akhir evaluasi. Metode yang digunakan untuk menganalisa tingkat perkembangan responden petani/peternak terhadap materi penyuluhan yang diharapkan yaitu melakukan pengukuran terhadap indikator menggunakan rating scale atau skala nilai kemudian ditabulasi dan diolah menggunakan garis continuum (Padmowiharjo, 2012). Sehingga interprestasi skor adalah skor tertinggi $25 \times 10 \times 4$ $=1000$ dan skor terendah $25 \times 10 \times 1=250$, menggunakan metode penunjukan langsung (purposive sampling) dan digambarkan dalam garis continuum . Untuk mengetahui efektivitas penyuluhan digunakan rumus (Ginting, 1991).

\section{HASIL DAN PEMBAHASAN}

Hasil kaji terap variasi suhu pada sistem pemeliharaan kandang closed house terhadap berat badan ayam broiler dilakukan yang berumur 12 hari sampai umur 21 hari dengan menggunakan metode korelasi dapat dilihat hasilnya sebagai berikut :

\section{Suhu Kandang Closed House}

Suhu adalah besaran yang menyatakan derajat panas dingin suatu benda untuk mengukur suhu adalah thermometer. Hasil penelitian suhu yang di dapatkan pada kandang closed house pada setiap sekatan mulai umur 12 hari - 21 hari dapat disimpulkan bahwa sekatan 1 yang paling bagus pertumbuhan ayam broiler (umur 21 hari) dengan suhu berkisar $25-29^{\circ} \mathrm{C}$, sedangkan sekatan 2 ayam broiler (umur 21 hari). 
Suhu berkisar $26-32^{\circ} \mathrm{C}$ dan sekatan 3 ayam broiler (umur 21 hari) suhu berkisar $28-33^{\circ} \mathrm{C}$. Hasil penelitian suhu yang didapatkan pada kandang closed house dilihat dari kisaran suhu yang diperoleh masih diatas standar suhu yang telah ditetapkan. Appelby et al. (2004) menyatakan, suhu lingkungan yang baik dalam pemeliharaan ayam broiler adalah $19-23^{\circ} \mathrm{C}$, Bell and Weaver (2000) menyatakan bahwa suhu nyaman untuk mencapai pertumbuhan optimum ayam broiler berkisar antara $18-23^{\circ} \mathrm{C}$, apabila suhu lingkungan terus meningkat akan mengakibatkan ayam mengalami stress dan melakukan proses homeostatis dengan cara panting, sehingga akan mempengaruhi ayam untuk mengkonsumsi pakan dalam jumlah yang sedikit dan menyebabkan penurunan produktivitas. Ayam akan panting pada suhu lingkungan $28^{\circ} \mathrm{C}$ atau ketika suhu tubuh ayam mencapai $42^{\circ} \mathrm{C}$. Panting adalah salah satu respon tingkah laku ayam broiler akibat stres dari suhu lingkungan yang panas dan juga mekanisme evaporasi melalui saluran pernafasan.

\section{Berat Badan Ayam Broiler}

Pertambahan berat badan adalah kenaikan berat badan yang dicapai oleh seekor ternak selama periode tertentu. Hasil penelitian yang telah dilakukan di kandang closed house berat badan ayam $(\mathrm{kg} / \mathrm{ekor})$ pada setiap sekatan mulai umur 12 hari - 21 hari dapat disimpulkan bahwa sekatan 1 yang paling bagus pertumbuhan berat badan akhir (umur 21 hari) adalah $1,03 \mathrm{Kg} /$ ekor ayam dengan suhu berkisar $25-29^{\circ} \mathrm{C}$, sedangkan sekatan 2 berat badan akhir (umur 21 hari) adalah $1 \mathrm{Kg}$ /ekor ayam dengan suhu berkisar $26-32^{\circ} \mathrm{C}$ dan sekatan 3 berat badan akhir (umur 21 hari) adalah $0,935 \mathrm{Kg}$ /ekor ayam dengan suhu berkisar $28-33^{\circ} \mathrm{C}$.

Hasil penelitian tersebut menunjukkan berat badan di sekatan 1 yang pertumbuhannya bagus dan masih bisa dinaikkan berat badannya tetapi, suhu didalam kandang harus lebih dikontrol serta pemberian pakan dan air minum lebih diperhatikan. Kandungan makanan yang menentukan performa pada ayam broiler adalah kandungan gizi yang seimbang antara protein dan energi, selain itu kebutuhan vitamin dan mineral juga harus terpenuhi. Jurnal Penilitian Krisna Praditiya Johan (2010) dikutip dalam penelitian Bonnet et al. (1997) menyatakan bahwa pertambahan berat badan ayam broiler umur enam minggu yang dipelihara pada suhu lingkungan $32^{\circ} \mathrm{C}$ sebesar 1.515 g/ekor sedangkan pada suhu $22^{\circ} \mathrm{C}$ pertambahan berat badan ayam broiler sebesar 1.984 g/ekor. Pertambahan berat badan ayam broiler pada minggu-minggu terakhir sebanyak 50 sampai 70 garam perhari, sehingga pertumbuhan tersebut harus diimbangi dengan ketersediaan pakan yang cukup (Amrullah, 2004).

Perbandingan berat badan akhir umur 21 hari ayam broiler dapat dilihat pada gambar 2 dibawah ini.

Sekatan 1

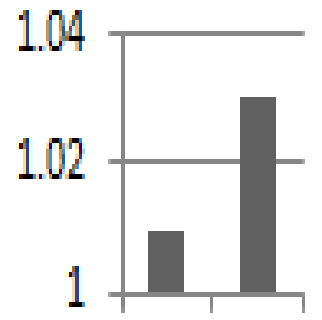

$25.4^{\mathrm{c}} 2 \mathrm{28.1 \textrm {C }}$

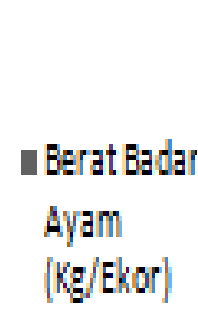

1.02
1
0.98
0.96

$26.5^{\circ} \mathrm{C} \quad 29.6^{\mathrm{t}} \mathrm{C}$
Sekatan 2

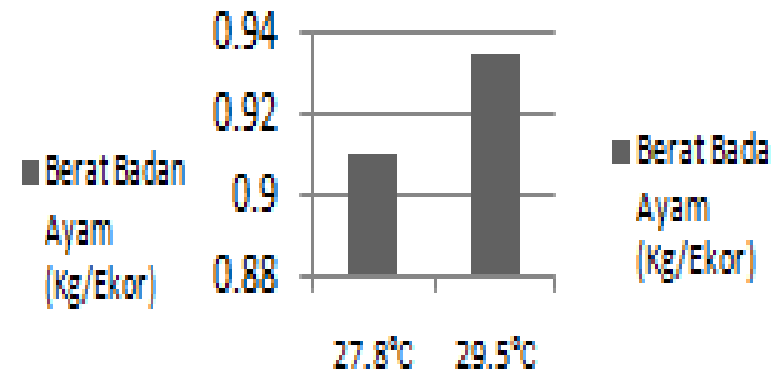

Gambar 2. perbandingan suhu dan berat badan ayam (kg/ekor) pada setiap sekatan umur 21 hari

Melihat dari gambar 2, hasil diagram batang perbandingan suhu dan berat badan ayam(kg/ekor) pada setiap sekatan umur 21 hari dapat disimpulkan bahwa sekatan 1 yang paling bagus pertumbuhan berat badan akhir (umur 21 hari) adalah $1,03 \mathrm{Kg} /$ ekor ayam dengan suhu

Diterbitkan Oleh, 
berkisar $25-29^{\circ} \mathrm{C}$, sedangkan sekatan 2 berat badan akhir (umur 21 hari) adalah $1 \mathrm{Kg} /$ ekor ayam dengan suhu berkisar $26-32^{\circ} \mathrm{C}$ dan sekatan 3 berat badan akhir (umur 21 hari) adalah $0,935 \mathrm{Kg} /$ ekor ayam dengan suhu berkisar $28-33^{\circ} \mathrm{C}$.

Sedangkan standar suhu untuk mencapai pertumbuhan optimum ayam broiler berkisar antara $18-23^{\circ} \mathrm{C}$ artinya ayam didalam kandang closed house yang berlokasi di Kampus II Politeknik Pembangunan Pertanian masih belum memenuhi standar suhu.

\section{Analisis Korelasi}

Analisis bivariat digunakan untuk menguji hipotesis pertama dan kedua, yaitu untuk mengetahui hubungan antara nilai suhu dengan pemahaman terhadap pengaruh berat badan ayam broiler pada sistem pemeliharaan kandang closed house (hipotesis 1), dan mengetahui hubungan antara nilai pengetahuan peternak ayam broiler dengan pertumbuhan berat badan ayam terhadap variasi suhu pada sistem pemeliharaan kandang closed house Rumus korelasi product moment menurut Arikunto Suharsimi (2002). Hasil nilai $r_{x y}$ yang didapat sesuai dengan rumus korelasi product moment menurut Suharsimi Arikunto (2002) yaitu $-0,594$.

Analisis korelasi sederhana dengan metode pearson atau sering disebut product moment peearson. Nilai korelasi (r) berkisar anatara 1 sampai -1, nilai semakin mendekati 1 atau -1 berarti hubungan anatara dua variabel semakin kuat, sebaliknya nilai mendekati 0 berarti hubungan anatara dua variabel semakin lemah. Nilai positif menunjukkan hubungan searah (X naik maka $\mathrm{Y}$ naik) dan nilai negative menunjukkan hubungan terbalik (X naik maka Y turun).

Variabel dalam penelitian ini meliputi satu variabel bebas yaitu suhu dalam kandang closed house (X), serta satu variabel terkait yaitu berat badan ayam broiler (Y). Berikut ini adalah skema hubungan variabel $\mathrm{x}$ dengan variabel $\mathrm{y}$. Menurut Jonathan Sarwono (2006) kekuatan hubungan antara dua variabel ada beberapa kriteria.

Hasil analisis korelasi sederhana (r) didapat korelasi antara suhu dengan berat badan ayam (Kg/Ekor) (r) adalah -0,594. Hal ini menunjukkan bahwa terjadi hubungan yang tinggi antara suhu dengan berat badan ayam (Kg/Ekor).
Sedangkan arah hubungan adalah negatif, karena nilai $r$ negatif berarti semakin tinggi suhu maka semakin menurunkan berat badan ayam (Kg/Ekor). Suhu yang tinggi akan membuat ayam mengalami stress dan melakukan proses homeostatis dengan cara panting, sehingga akan mempengaruhi ayam untuk mengkonsumsi pakan dalam jumlah yang sedikit dan menyebabkan penurunan produktivitas.

\section{Respon Petani Terhadap Kajian Materi}

Adapun penyuluhan yang dilakukan di Desa Bunga Ejaya dibuat dalam bentuk Lembaran Persiapan Menyuluh (LPM) seperti pada Lampiran 6. Responden adalah anggota Kelompok Tani Gammang yang terdapat di Desa Bunga Ejaya dengan karakteristik beragam, kisaran umur 30-75 tahun, dengan jumlah tanggungan keluarga berkisar 1-5 orang. Tingkat pendidikan formal masih tergolong rendah dimana pendidikan responden mayoritas $(60 \%)$ tamat $\mathrm{SD}$, oleh karena itu dapat ditingkatkan melalui pendidikan non formal baik melalui kegiatan penyuluhan dan kunjungan yang terkait dengan kebutuhan kelompok sehingga memiliki sikap inovatif.

\section{Pelaksanaan Penyuluhan}

Kegiatan penyuluhan dilaksanakan dua kali yaitu pada hari Kamis, tanggal 14 Mei 2020 dan pada hari Rabu, tanggal 20 Mei 2020. Tempat penyuluhan pertama dilakukan di rumah Ketua Kelompok Tani dan penyuluhan kedua dilakukan di rumah anggota Kelompok Tani Gammang Kec. Pallangga, Kab.Gowa. Kegiatan penyuluhan dilaksanakan bersama Ketua Kelompok Tani Gammang dengan mengundang petani responden dari Kelompok Tani Gammang sebanyak 25 orang. Materi penyuluhan yang dibawakan yaitu tentang "Pengaruh Variasi Suhu Terhadap Pertambahan Berat Badan Ayam Broiler Pada Sistem Pemeliharaan Kandang Closed House". Dengan isi materi tingkat pengetahuan peternak tentang variasi suhu terhadap pertambahan berat badan ayam broiler pada sistem pemeliharaan kandang closed house. Kegiatan penyuluhan menggunakan media Folder.

\section{Evaluasi Penyuluhan Pertanian}

Pelaksanaan kegiatan penyuluhan kepada Kelompok Tani Gammang, sasaran yang ingin 
dicapai adalah adanya peningkatan pengetahuan sehingga mempunyai kemampuan menerima dan melaksanakan suatu inovasi baru yang dapat diterapkan dalam usaha taninya sehingga dapat meningkatkan pendapatannya. Pendekatan yang dilakukan dalam melaksanakan kegiatan penyuluhan berupa pendekatan kelompok dan individu.

\section{Evaluasi Penyuluhan}

Evaluasi yang telah dilakukan adalah evaluasi awal dan evaluasi akhir. Alat yang digunakan untuk mengukur tingkat pengetahuan responden adalah kuesioner dan digambarkan dalam garis continuum dengan jumlah pertanyaan seperti pada lampiran 3, sebanyak 10 pertanyaan untuk pengetahuan dengan nilai tertinggi adalah 4 dan nilai terendah 1 . Tinggi rendahnya tingkat pengetahuan responden dapat ditentukan melalui jawaban responden dari tiap-tiap pertanyaan dalam evaluasi awal dan evaluasi akhir. Dengan responden anggota Kelompok Tani Gammang sebanyak 25 orang.

\section{Tingkat Pengetahuan Responden}

Tingkat pengetahuan responden dapat diartikan sebagai kenyataan yang dimengerti dan diketahui oleh Kelompok Tani Gammang mengenai pengaruh variasi suhu terhadap pertambahan berat badan ayam broiler pada sistem pemeliharaan kandang closed house. Pada evaluasi tingkat pengetahuan terdapat 10 (sepuluh) pertanyaan untuk evaluasi awal dan evaluasi akhir.

a. Hasil Evaluasi Awal

Hasil evaluasi awal responden berjumlah 25 orang dengan jumlah pertanyaan untuk tingkat pengetahuan berjumlah 10 pertanyaan dengan 4 (empat) kriteria. Pengetahuan responden tentang pengaruh variasi suhu terhadap pertambahan berat badan ayam broiler pada sistem pemeliharaan kandang closed house, sebelum penyuluhan adalah 501.

Jika digambarkan dengan garis continuum adalah sebagai berikut :

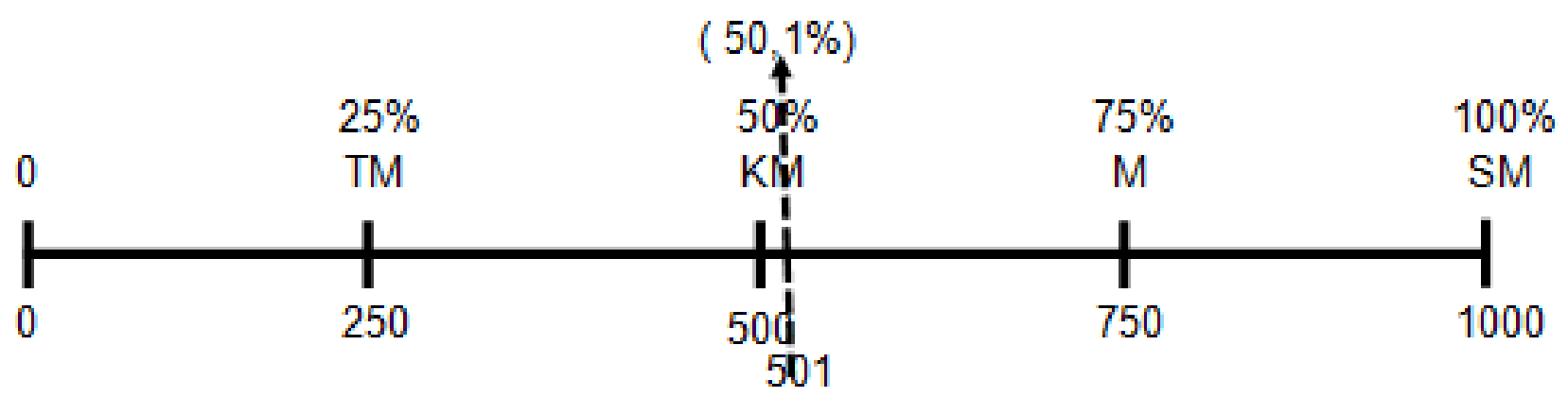

Gambar 3. Garis continuum tingkat pengetahuan pada evaluasi awal. Ket $: \mathrm{TM}=$ Tidak Mengetahui; $\mathrm{KM}=$ Kurang Mengetahui; $\mathrm{M}=$ Mengetahui; $\mathrm{SM}=$ Sangat Mengetahui

Garis continuum di atas menunjukkan bahwa sebelum penyuluhan dilakukan, pengetahuan peternak tentang pengaruh variasi suhu terhadap pertambahan berat badan ayam broiler pada sistem pemeliharaan kandang closed house, berada pada skor 501 atau persentase $50,1 \%$ yang berarti masih berada pada kriteria "kurang mengetahui”. b. Hasil Evaluasi Akhir

Hasil evaluasi akhir responden berjumlah 25 orang dengan jumlah pertanyaan untuk tingkat pengetahuan berjumlah 10 pertanyaan dengan 4 (empat) kriteria. Pengetahuan responden tentang pengaruh variasi suhu terhadap pertambahan berat badan ayam broiler pada sistem pemeliharaan kandang closed house, sebelum penyuluhan adalah 822.

Diterbitkan Oleh, 


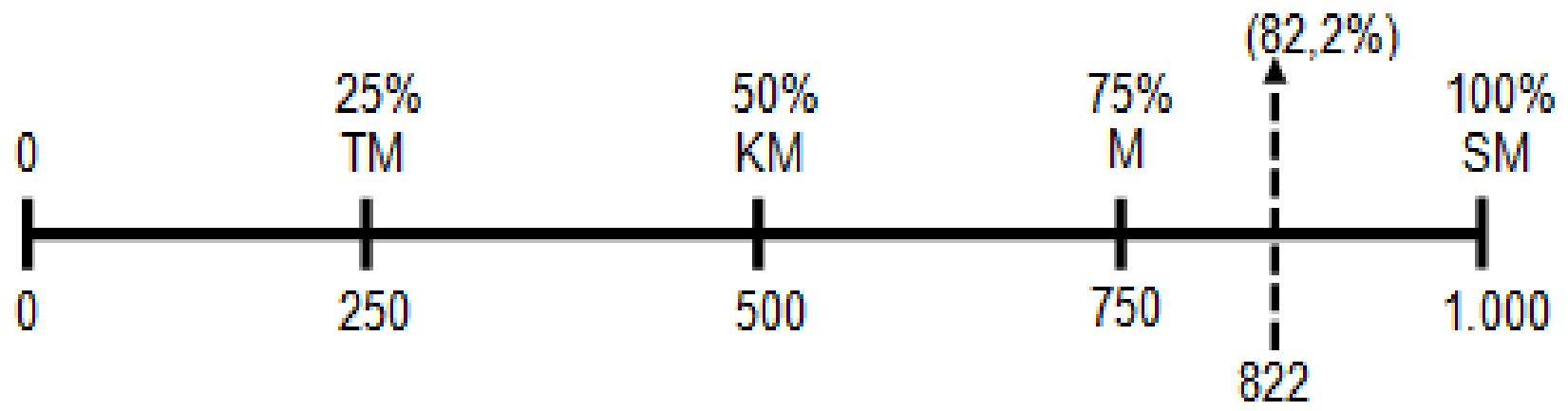

Gambar 4. Garis continuum tingkat pengetahuan pada evaluasi akhir. Ket $: \mathrm{TM}=$ Tidak Mengetahui; $\mathrm{KM}=$ Kurang Mengetahui; $\mathrm{M}=$ Mengetahui; $\mathrm{SM}=$ Sangat Mengetahui

Garis continuum di atas menunjukkan bahwa setelah penyuluhan dilakukan, pengetahuan peternak tentang pengaruh variasi suhu terhadap pertambahan berat badan ayam broiler pada sistem pemeliharaan kandang closed house, berada pada skor 822 atau persentase $82,2 \%$ yang berarti sudah berada pada kriteria "mengetahui".

\section{Efektifitas Penyuluhan}

Evaluasi penyuluhan merupakan salah satu bagian untuk menentukan efektifitas dan dampak penyuluhan sesuai dengan tujuan yang ingin dicapai. Efektivitas penyuluhan menggunakan rumus Ginting (1991). Berdasarkan kriteria penilaian yang telah ditentukan, maka pelaksanaan penyuluhan yang telah dilakukan termasuk kategori cukup efektif yaitu 64\%. Adanya kegiatan penyuluhan maka diharapkan pengetahuan peternak dapat ditingkatkan.

\section{KESIMPULAN}

\section{Kesimpulan}

Berdasarkan hasil penelitian dan penyuluhan, maka dapat diambil kesimpulan bahwa :

1. Setelah melakukan penelitian suhu berpengaruh terhadap berat badan ayam broiler. Hasil ini dilihat dari pengamatan pada penelitian yang dimana sekatan 1 yang paling bagus pertumbuhan berat badannya dengan berat akhir (umur 21 hari) yaitu $1,03 \mathrm{Kg}$ /ekor ayam dengan suhu berkisar $25-29^{\circ} \mathrm{C}$. Standar suhu untuk mencapai pertumbuhan optimal ayam broiler berkisar antara $18-23^{\circ} \mathrm{C}$ karena setelah melakukan penelitian suhu berpengaruh terhadap berat badan ayam broiler jadi, kita harus mengontrol suhu lingkungan kandang ayam agar pertumbuhan ayam bagus dan ayam tidak mengalami panting karena ayam akan panting pada suhu lingkungan $28^{\circ} \mathrm{C}$ atau ketika suhu tubuh ayam mencapai $42^{\circ} \mathrm{C}$.

2. Hasil evaluasi penyuluhan di Desa Bunga Ejaya, Kecamatan Pallangga, Kabupaten Gowa, tanggapan peternak atau anggota Kelompok Tani Gammang tentang pengaruh variasi suhu terhadap pertambahan berat badan ayam broiler pada sistem pemeliharaan kandang closed house yang disampaikan memberikan perubahan pengetahuan dari $50,1 \%$ menjadi $82,2 \%$, sehingga efektifitas penyuluhan mencapai $64 \%$ berada pada tingkat cukup efektif.

\section{DAFTAR PUSTAKA}

Appelby, M. C., J. A. Mech dan B. O. hunghes. 2004. Poultry Behaviour and Welfareb. CABI. Publishing. Wallingford. Oxfordshire. London. , 2006. Undang-undang RI No. 16 tahun 2006 tentang Sistem Penyuluhan Pertanian,Perikanan dan Kehutanan. Jakarta , 2009. Peraturam Menteri Pertanian Nomor25/Permentan/OT.140/5/2009 tentang Pedoman penyusunan Programa Penyuluhan Pertanian. Jakarta: Departemen Pertanian.

Church and Pond.2010. Basic Animal Nutrition dan Feeding.4th Edition.John Wiley and 
Sons Inc, New York, USA.

Fadilah, R. 2010. Ayam Broiler Komersial. Agromedia Pustaka. Jakarta Erwin. 2012. Mengevaluasi Pelaksanaan Penyuluhan Pertanian. Bahan Diklat Sertifikasi Penyuluh Pertanian Level Supervisor. Bapeltan, Jambi.

Jonathan, Sarwono. 2006. Metode Penelitian Kuantitatif Dan Kualitatif. Yogyakarta: Graha Ilmu.

Mardikanto. T, 1993, Penyuluhan Pembangunan pertanian. Sebelas Maret University Press, Surakarta

Padmowihardjo,S. 2002. Evaluasi Penyuluhan Pertanian. Modul Universitas Terbuka,Jakarta. . 2006. Tujuan Evaluasi Penyuluhan Pertanian. Modul Universitas Terbuka, Jakarta. . 2012. Evaluasi Penyuluhan Pertanian, Pusat Penelitian Universitas Indonesia.Depdiknas, Jakarta.

Prihatman. K. 2002. Budidaya Ayam Broiler. Jurnal. intek. Go. Id. Sistem Informasi
Manajemen Pembangunan Pengembangan Ekonomi Masyarakat di Pedesaan. Badan Perencanaan Pembangunan Nasional. Jakarta.

RPJM , 2016. Rencana Pembangunan Jangka Menengah Desa Bunga Ejaya Kecamatan Pallangga Kabupaten Gowa Tahun 2017.

Talib, C., I. Inounu, dan A. Bamualim. 2007. Restrukrisasi Peternakan diIndonesia.Analisis Kebijakan Petanian. Volume 5 NO. 1, Maret 2007:1-14.

Sugiyono. 2010. Metode Penelitian Kuantitati, Kualitatif $R$ dan $D$. Bandung. Alfabeta.

Wahju, J. 2004. Ilmu Nutrisi Unggas. Edisi Keempat. Universitas Gadjah Mada Press, Yogyakarta . 2014. Ilmu Nutrisi Ternak Unggas. Gadjah Mada University Press, Yogyakarta.

Weaver Jr., W. D. 2001. Poultry Housing. In: Commercial Chicken Meat and Egg Production, 5 ${ }^{\text {th }}$ Edition, (Ed. Donald D. Bell and William D. Weafer Jr.). pp. 102103. 